Agro Ekonomi Vol. 28/No. 2, Desember 2017

\title{
FACTORS AFFECTING PROFITABILITY ON ANIMAL FEED COMPANIES IN INDONESIA
}

\section{Faktor Faktor yang Mempengaruhi Profitabilitas Perusahaaan Pakan Ternak di Indonesia}

\author{
Mercky Haryo, Amzul Rifin, Bunasor Sanim \\ Graduate Program of Management and Business, Bogor Agricultural University \\ Gedung SB IPB, Jl. Raya Pajajaran Bogor, Indonesia 16151 \\ merckyharyo@gmail.com
}

Diterima tanggal : 16 Juni 2017 ; Disetujui tanggal : 15 Desember 2017

\begin{abstract}
The animal feed industry is essential as it supports livestock industry in meeting the need of protein of a country. Feed contribution reaching at 70 percent of livestock production cost makes feed becomes an pivotal factor which could boost its sales. Unfortunately net income of animal feed companies for the last five years tent to decrease and emerged problems. The aim of this study were to examine internal and external factors affecting profitability represented by ROA and formulate recommendations in improving them. The results showed that internal factors affecting ROA significantly are Sales, COGS, and TATO, while for the external factor is exchange rate. DAR, inflation and international corn prices do not influence ROA significantly. The implications for companies and animal feed industries in improving profitability generally is by increasing sales and TATO value. Also, the company must be able to press COGS especially raw material cost which is more sensitive to profitability when its price is higher. Companies have to conduct risk management in order to anticipate exchange rate volatility followed by government's action as regulator in maintaining macroeconomic and trade stability.
\end{abstract}

Keywords : animal feed, financial performance, macroeconomic, $R O A$

\section{INTISARI}

Industri pakan ternak merupakan pendukung industri peternakan dalam memenuhi kebutuhan protein dalam negeri. Kontribusi pakan yang mencapai 70 persen dalam biaya produksi menjadikannya sebagai faktor yang penting dalam budidaya ternak. Hal ini menjadikan penjualan pakan ternak terus meningkat tiap tahunnya namun sebaliknya laba bersih perusahaan pakan ternak cenderung menurun selama lima tahun terakhir yang menjadi masalah krusial bagi perusahaan. Tujuan dari penelitian ini adalah mengetahui faktor-faktor dari internal yaitu kinerja keuangan perusahaan dan eksternal perusahaan yaitu makroekonomi yang mempengaruhi profitabilitas (ROA) serta memberikan rekomendasi peningkatannya. Hasil penelitian menunjukkan faktor internal secara signifikan berpengaruh adalah sales, COGS, TATO dan faktor eksternal adalah kurs. Variabel DAR, inflasi, dan harga jagung internasional tidak berpengaruh secara signifikan. Implikasi bagi perusahaan dan industri pakan ternak pada umumnya untuk meningkatkan profitabilitas adalah dengan meningkatkan sales dan TATO dengan menerapkan strategi-strategi seperti bauran pemasaran. Perusahaan juga harus mampu 
menekan biaya COGS terutama bahan baku dimana peningkatannya bersifat sensitif berpengaruh terhadap profitabilitas. Perusahaan juga harus melakukan manajemen risiko untuk mengantisipasi fluktuasi kurs diikuti peran aktif pemerintah selaku regulator dalam menjaga stabilitas makroekonomi dan perdagangan.

Kata Kunci : kinerja keuangan, makroekonomi, ROA, perusahaan pakan ternak

\section{INTRODUCTION}

The livestock industry has good prospect in Indonesia to meet the needs of nations animal protein. Indonesia has large people population but poultry consumption still among the lowest among ASEAN countries at $7 \mathrm{~kg} /$ capita / year, makes Indonesia a potential market for livestock industry. Chicken meat was known to have high protein content and source of important vitamins and minerals that useful for various processes in the body so it can become of source for the improvement of peoples nutrition. Livestock industrial scale production continues to increase followed to national livestock population that increased over last five years (OECD, 2015).

Animal feed industry supports livestock industry to provide feed, which contributes 70 percent of livestock production cost makes feed as an important factor in livestock farm (GPMT, 2016). Animal feed demand tend to increase by 8,3 percent annually with 2015 domestic consumption by 15.9 million Ton and is predicted to reach nine percent in 2016 (GPMT, 2016). There are several animal feed companies with large production and market share in Indonesia sequentially are;
PT. Charoen Pokphand Indonesia (CPIN) of 5.4 million tons and a market share of 34 percent, PT Japfa Comfeed (JPFA) of 4.1 million tons and a market share of 24 percent, PT. Malindo Feedmill (MAIN) of 1.3 million tons and 8 percent market share, and PT. Sierad Produce (SIPD) of 8 million tons and 5 percent market share (DBS 2014).

The livestock feed companies mentioned above are a large-scale companies that have large assets and technology that similar or not much different from each other to conduct the main business line activities (Core Business) to produce livestock feed and vertical business integration, both from upstream with animal feed products and Day Old Chick (DOC) to downstream for chicken meat and egg products. The market share of the four companies was equal to 71 percent makes the profile of the four companies can be reflection of the livestock feed industry in Indonesia, which according to Fitriani (2006) competition of animal feed industry in Indonesia is oligopoly which mean is a combination of several leading companies with a market share of 60 to 100 percent and the company's strategic policies often depend on the policies taken by its closest competitor. These companies have 
also become public listed companies (Tbk) and listed in the Indonesia Stock Exchange on the Basic and Chemical Industry Sector with Animal Feed sub-sector.

These companies' ability on market products is good where the value of net sales increased every year. It shows an indication of net profit increased, but actually net profits of companies are likely to decrease. Decrease in net income of companies was a crucial issue for every business performance, including animal feed companies. The company's performance can be seen from the level of profitability and measured using financial ratios Return on Assets (ROA) which illustrates the overall effectiveness of management in generating profits with its available assets (Gitman, 2009). Animal feed company profitability ROA decreased along with the decrease in net income earned in period 2010-2015.

The company's profitability is influenced by internal factors and external factors, internal factors are the level of Sales that became a source of revenue, Cost of Goods Sold in production of product, effectiveness of assets management in generating sales, and proportion of assets using debt financing (Gitman, 2009). External factors that used on this study are Corn Prices, as an important raw materials for compotition needs on animal feed (Tangendjaja, 2007) which imported with international prices, Exchange Rates that have fluctuates also
Inflation that led to rising prices of production inputs outputs and decrease in people purchasing power. The aims of this study is to determine internal and external factors that affect animal feed company's profitability and its impact, also formulate recommendations to improved profitability of animal feed company.

Studies on the animal feed industry and determinants of profitability had been done by researchers, but profitability studies with main object animal feed companies is still not widely done. Wardjojo et al. (2016) study the effect of working capital liquidity on the profitability of poultry companies listed in Indonesia Stock Exchange period 2006-2014 using panel data regression method. The result showed that receivable turn over significantly influence ROA profitability. Fitriani (2006) studied the analysis of the structure, behavior and performance of the chicken feed industry in Lampung and West Java provinces. The results showed there is close correlation between structure, behavior and performance of poultry feed industry where feed prices will attract competitors to enter or out of industry and the entry of new competitors into the industry pushed the company to reduce the cost of production impact on cost efficiency and output price of feed.

Research on the influence of internal factors on corporate profitability in sectorial index done by Margaretha and Suparthika (2016), examined PEFINDO Index 25 
year 2007-2012 with result that sales growth, labor productivity and industry affiliation have positive effect on ROA. Rice (2014) examined the Compass 100 Index with TATO results have a positive and significant impact on profitability ROE.

\section{METHODS}

\section{Types and Sources of Data}

The study was conducted in the financial sphere where data used in this research as internal factors from financial statements of four biggest companies in animal feed production and market share in Indonesia name respectively PT Charoen Pokphand Indonesia (CPIN), PT Japfa Comfeed (JPFA), PT Malindo Feedmill (MAIN) and PT Sierad Produce (SIPD) published quarterly from first quarter of 2010 until fourth quarter of 2015. Data used as external factors were exchange and inflation rate from Central Bank of Indonesia (BI), and international corn prices from Investing.com. Data collection and research were conducted in December 2016. The definition and hypothesis of research data presented in Table 1.

\section{Data Processing Techniques}

Data processing in this study was quantitative methods using multiple regression, in which mathematical equation allows and is able to predict the values of a dependent variable using values of one or more independent variables (Nachrowi and Usman, 2006). The regression was conducted using panel data method. Panel data was used to combines cross section sample of four companies and time series of quarter monthly observation during 20102015 simultaneously resulting in 96 points of observation (four companies multiply by four-quarter multiply by six-year), and data processed by software EViews 9 .

There were three techniques for estimating panel data model, namely: Common Effect Model (OLS), Fixed Effect Model (FEM), and Random Effects Model

Table 1 Definition and hypotheses of data

\begin{tabular}{llcc}
\hline \multicolumn{1}{c}{ Variable } & \multicolumn{1}{c}{ Definition } & Unit & Hypotheses \\
\hline $\begin{array}{l}\text { Independent Variable } \\
\text { Return on Assets }\end{array}$ & Net income divided by total assets & $\%$ & \\
$\begin{array}{l}\text { Dependent Variable } \\
\text { Internal Factor }\end{array}$ & & & \\
1. Sales & Total sales on given period & IDR & $(+)$ \\
2. Debt Asset Ratio & Total debt divided by total assets & $\%$ & $(-)$ \\
3. Total Asset Turnover & Ratio of sales divided by total assets & $\%$ & $(+)$ \\
4. Cost of Goods Sold & Costs incurred procurement of product & IDR & $(-)$ \\
External Factor & & & \\
1. Kurs & Exchange rate & IDR/USD & $(-)$ \\
2. Inflation & Increase prices on given period & $\%$ & $(-)$ \\
3. Corn & International corn price & USD/Bushel & $(-)$ \\
\hline
\end{tabular}


Table 2 Animal feed companies financial profit statement

\begin{tabular}{lrrrrrr}
\hline \multicolumn{1}{c}{ Companies } & \multicolumn{6}{c}{ Year } \\
CPIN & 2010 & 2011 & 2012 & 2013 & 2014 & \multicolumn{1}{c}{2015} \\
\hline Net Sales (Triliun Rp) & & & & & & \\
Net Profit (Triliun Rp) & 15.077 & 17.957 & 21.31 & 25.66 & 29.15 & 30.107 \\
Net Profit per Sales (\%) & 2.219 & 2.362 & 2.68 & 2.531 & 1.745 & 1.832 \\
\hline JPFA & 14.72 & 13.15 & 12.58 & 9.86 & 5.99 & 6.08 \\
\hline Net Sales (Triliun Rp) & & & & & & \\
Net Profit (Milyar Rp) & 13.956 & 15.633 & 17.833 & 21.412 & 24.459 & 25.023 \\
Net Profit per Sales (\%) & 959 & 617 & 992 & 595 & 34 & 468 \\
\hline MAIN & 6.87 & 3.95 & 5.56 & 2.78 & 1.39 & 1.87 \\
Net Sales (Triliun Rp) & & & & & & \\
Net Profit (Billions Rp) & 2.036 & 2.634 & 3.349 & 4.193 & 4.502 & 4.775 \\
Net Profit per Sales (\%) & 179 & 205 & 302 & 242 & -84 & -62 \\
\hline SIPD & 8.79 & 7.78 & 9.02 & 5.77 & -1.87 & -1.3 \\
Net Sales (Triliun Rp) & & & & & & \\
Net Profit (Billions Rp) & 3.643 & 4.029 & 4.354 & 3.854 & 2.505 & 2.113 \\
Net Profit per Sales (\%) & 61 & 22 & 15 & 13 & 3 & -362 \\
\hline
\end{tabular}

Source: Company financial statement (2010-2015)

(REM). In determining best panel data model, several tests were applied, such as Chow test to determine model of OLS or FEM, Haussmann test to determine model FEM or REM and Multiple Langrage to determine model of REM or OLS (Nachrowi and Usman, 2006).

\section{Model Research}

The multiple regression model used in the study that had been explained in Data Processing Techniques was:

$$
\begin{aligned}
& \text { ROA }_{(i, t)}=\beta_{1, i}+\beta_{2} \operatorname{lnSales}_{i, t}+ \\
& \beta_{3} \operatorname{lnCOGS}_{i, t}+\beta_{4} \text { TATO }_{i, t}+ \\
& \beta_{5} \text { DAR }_{i, t}+\beta_{6} \text { Kurs }_{i, t}+\beta_{7} \operatorname{Inf}_{i, t}+ \\
& \beta_{8} \operatorname{Corn}_{i, t}+\varepsilon_{i, t}
\end{aligned}
$$

Where:

$$
\begin{array}{ll}
\text { ROA } & =\text { Return on Assets } \\
\beta & =\text { Slope } \\
\text { LnSales } & =\text { Sales }
\end{array}
$$

$$
\begin{array}{ll}
\text { LnCOGS } & =\text { Cost of Goods Sold } \\
\text { DAR } & =\text { Debt Asset Ratio } \\
\text { TATO } & =\text { Total Asset Turnover } \\
\text { Kurs } & =\text { IDR / USD rate } \\
\text { Inf } & =\text { Inflation rate } \\
\text { Corn } & =\text { Corn Price } \\
\mathrm{i} & =\text { i-th individual } \\
\mathrm{t} & =\text { time period to- } \mathrm{t} \\
\varepsilon & =\text { error }
\end{array}
$$

\section{RESULTS AND DISCUSSION}

Descriptive financial profit data

There is a trend that Net Sales of companies were increases with the biggest increase is CPIN and holds the largest market share. Followed by JPFA, MAIN and the lowest Net Sales are SIPD.

But this increase of Net Sales doesn't followed by increasing of Net profit but the opposite it comes decline with the 
lowest Net Profit is SIPD. For the complete financial profit data showed on Table 2 .

\section{Hypothesis test results}

Based on the chow test, panel data chosen model is FEM where there are more significant variable and adjusted R-square is larger than the OLS model. Representation of FEM model output is presented in Table 3 with the regression model as follows:

$$
\begin{aligned}
\mathrm{ROA}= & 0.747608+0.253521 * \mathrm{SALES}- \\
& 0.259038 * \mathrm{COGS}+0.011031 * \mathrm{TATO} \\
& -0.010401 * \mathrm{DAR}-0.073489 * \mathrm{KURS} \\
& -0.0000633 * \mathrm{IN} \text { F L A S I }- \\
& 0.0000196 * \mathrm{CORN}
\end{aligned}
$$

Table 3 Equation result of ROA

\begin{tabular}{lrr}
\hline \multicolumn{1}{c}{ Variable } & \multicolumn{1}{c}{ Coeff. } & \multicolumn{1}{c}{ Prob. } \\
\hline C & 0.7476 & 0.0000 \\
Sales & $* * * 0.2535$ & 0.0000 \\
COGS & $* * *-0.259$ & 0.0000 \\
TATO & $* 0.0110$ & 0.0611 \\
DAR & -0.0104 & 0.5258 \\
Kurs & $* * *-0.0734$ & 0.0000 \\
Inflasi & -0.0001 & 0.9529 \\
Corn & 0.0000 & 0.2202 \\
\hline R-squared & 0.8457 & \\
F-statistic & 46.5710 & 0.0000 \\
Durbin-Watson stat & 1.6917 & \\
\hline
\end{tabular}

Description: significance level: ${ }^{*} p<0,1$ $* * * p<0,01$

Source: Companies financial statements processed with Eviews 9 (2016)

\section{Variables Analysis}

\section{Sales}

Sales has increasing trend with an average of IDR 3.147 trillion. The highest sales value is in the second quarter of 2014 CPIN of IDR 7.720 trillion and the lowest sales is in the first quarter of 2010 amounted to IDR 449 billion by MAIN. The company with the highest sales is CPIN amounted to IDR 5.802 trillion and an average company with the lowest sales is SIPD amounted to IDR 854 billion. The regression results in Table 3 shows sales coefficient is 0,2535 and 0,0000 probabilities showed significant positive sales effect on ROA at 99 percent confidence level with a sense that if the value of sales increased one percent will increase ROA by 0,2535 percent ceteris paribus. These results are consistent with the hypotheses that spouse their initial positive and significant relationship between variables of sales and ROA (figure 1).

The research result is in line with previous studies conducted by Anum (2014), Bhayani (2010) and Sanjay (2010) reflects that companies in this study averagely can perform positive sales. Growth in consumption of meat and eggs increased every year makes growth in the number of livestock animals makes the selling animal feed and DOC rate increased.

\section{Cost of Goods Sold (COGS)}

Variable of COGS has a rising trend with an average of IDR 2.578 trillion. COGS highest value in the fourth quarter of 2014 amounted to IDR 6.621 trillion by CPIN and the lowest value of COGS in the 


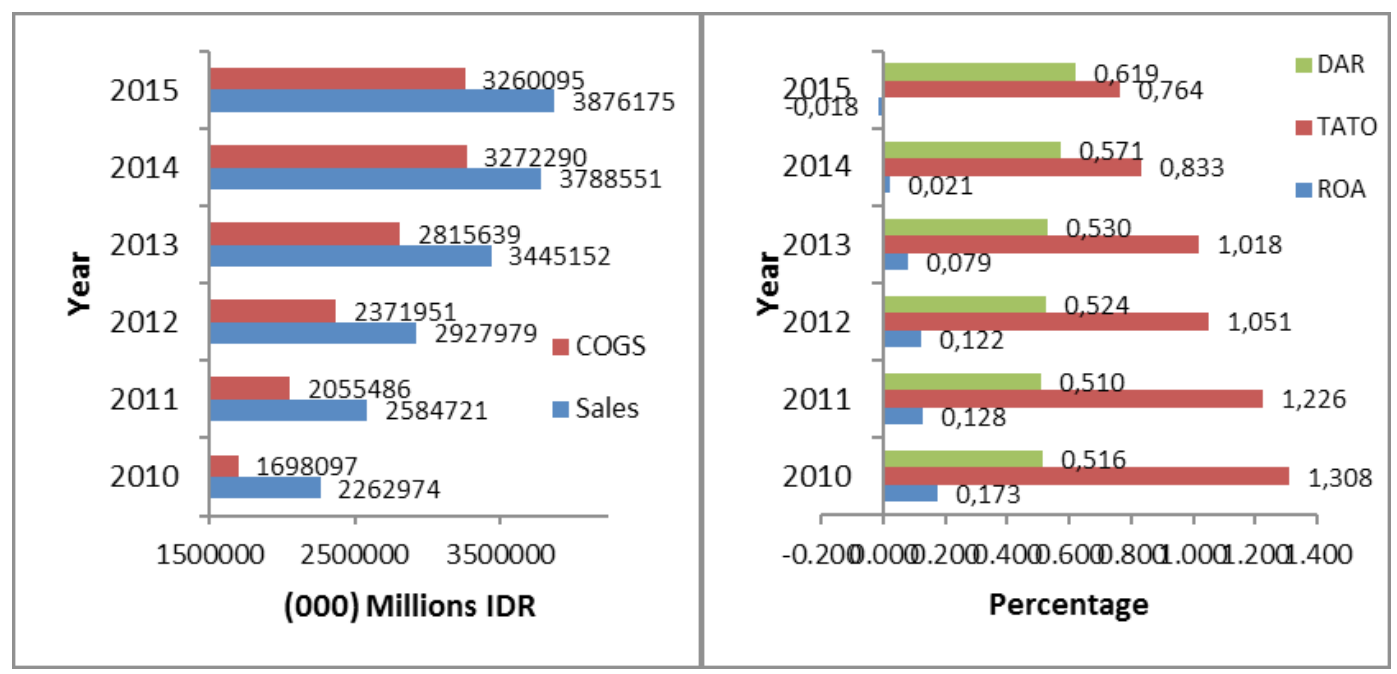

Figure 1 Company's internal factor and ROA result

second quarter of 2010 amounted to IDR 367 billion by MAIN. Companies with the highest COGS is CPIN amounted to IDR 4.694 trillion, and the company with the lowest average COGS is SIPD amounted to IDR 749 billion. The regression results in Table 3 shows the coefficient COGS is $-0,4534$ and 0,0000 probabilities indicate COGS significant negative effect on ROA at 99 percent confidence level with a sense that ifCOGS increased by one percent would decrease 0,4534 percent ROA ceteris paribus.

These results are consistent with the hypotheses that spouse their initial negative and significant relationship between the variables COGS and ROA (Figure 1). Results of research consistent with research by Hidayat (2015), Anum (2014), Putu (2014), Akotey (2013), and Almajali (2012).

Nearly 75 percent of animal feed COGS is the cost of raw materials which need large amounts and continuity. Most of the raw material needs met from domestic and the rest is imported. Imported raw materials have the risk of exchange rate depreciation which will result in an increase in prices that affect COGS.

\section{Total Asset Turn Over (TATO)}

Average trend of TATO has decreased 71 percent from 1,3 to 0,76 times turnover. The average TATO value is 1,03 times means every IDR invested in assets able to generate sales of IDR 1,033 or 1,033 times. Animal feed company with the highest TATO is CPIN by 1,14 times and the company with the lowest TATO is SIPD of 0,82 times. CPIN has total assets on average 6,5 times more than MAIN however TATO value of MAIN is almost equal to the TATO value of CPIN of 1,12 times exceed JPFA which have assets and sales larger than MAIN, MAIN 
indicates better effectiveness and efficient management of assets becoming more productive in generating sales compared to JPFA and SIPD. The regression results in Table 3 shows the coefficient value of 0,011 and 0,061 probability. It implies that TATO has significant positive effect on ROA at 90 percent confidence level with TATO sense if the value increases by one percent, it ROA will increase by 0,011 percent ceteris paribus.

These results are consistent with the initial hypotheses that spouse their significant and positive relationship between the variables TATO and ROA (Figure 1). The research result is in line with research conducted by Winarno (2015), Dwiarti (2014), Barus (2013) and Noor (2011). The decreased trends of TATO illustrates that the rate of increase of company's assets is higher than the level of sales generated by these assets, it indicates the management of assets in generating sales are not maximum so that assets become less productive.

\section{Debt Asset Ratio (DAR)}

Average DAR trend was increased by 20 percent from 0,516 becomes 0,619 with an average of 0,5450 describe that 54,50 percent of total assets financed by debt which on average. The company is able to pay off all the debt using all its assets and companies not funding all of its assets only by debt. Maximum DAR value is in the first quarter of 2010 by MAIN with values of 0,85 , and the minimum is in the third quarter of 2011 by CPIN with values of 0,27 . Company with lowest DAR is CPIN with values of 0,3668 below average DAR value, this shows that CPIN choose to fund 63 percent of its assets using other than debt financing. Companies with the highest DAR is MAIN with values of 0,68 followed by JPFA with values of 0,61 showed more than half of total assets is financed by debt so that the risk of interest rates and finance charges of JAPFA and MAIN is higher than CPIN and SIPD.

The regression results in Table 3 shows the coefficient of $-0,0104$ and 0,5258 probability shows variable DAR have non-significant negative effect on ROA at 95 percent level of confidence with DAR sense increase or decrease has no significant effect on the ROA. These results are not in line with the initial hypothesis of the study that spouse negative and significant relationship between the variables DAR and ROA. The research result is in line with previous studies conducted by the Dewi (2015), Ruspandi (2014), Okwo (2012), and Ashvin (2012). Although not significant, the negative effect of DAR on ROA can be seen on DAR trend that increasing in the opposite direction with ROA decline each year (Figure 1).

The increase in debt component on animal feed company assets due to 
company's needs of funding for operational activities, expansion of business development and financial expenses pay off in short time. Additional funds from the internal hard to obtain because of companies condition which loss and decline earnings and the unavailability of retained earnings, so companies using external funding sources that allow gained in relatively fast.

\section{Exchange rate}

The movement of the rupiah exchange rate fluctuates with the weakening trend over US dollar. The average value of exchange rate is IDR 10.650 / USD where the highest rate of IDR 14.657 / USD in the third quarter 2015 and the lowest rate of IDR 8.597 in the second quarter of 2011. Results in Table 3 shows the regression coefficient of $-0,0735$ and probability equal to 0,0000 show that the exchange rate significant negative effect on ROA at 99 percent confidence level with a sense that if the exchange rate increases by one percent would reduce ROA amounted to 0,07345 percent ceteris paribus.

These results are consistent with the initial hypothesis that suppose to be significant and negative relationship between the variable exchange rate and ROA. These results are consistent with research from Karmilah (2015) and Suardani (2009). Fluctuations of exchange rate impact on the animal feed industry where most raw materials are imported makes its price become more expensive which increases the cost of goods sold and increase the financial costs of foreign exchange losses thus reducing the profitability of companies.

\section{Inflation}

The inflation rate has a rising trend with an average of 5,76 percent. The highest inflation rate of 8,4 percent in the third quarter of 2013 and the lowest rate of inflation of 3,35 percent in the fourth quarter of 2015. Results in Table 3 shows the regression coefficient $-0,0000633$ and 0,9529 probability makes inflation rate is not significant negative on ROA at level of confidence 95 percent with a sense increase or decrease of inflation has no significant effect on ROA.

These results are not consistent with the initial hypothesis that suspect inflation has significant effect on ROA. The results are consistent with research Karmilah (2015), Halim (2013), Kalengkongan (2013), and Pervan (2010). Inflation rates does not give a direct effect on the animal feed industry, seen from the decline in the inflation rate in 2014 to 2015 were not accompanied by an increase in ROA. Inflation makes negative second round effect in animal feed company with a rise in operating expenses and a decrease in purchasing power. 


\section{International Corn Price}

International corn prices shows downward trend in prices with an average price of 517 USD / bushel. The highest price of 763 USD / bushel in the third quarter of 2012 and the lowest price 320 USD / bushel in the third quarter of 2014. Results in Table 3 shows regression coefficient is $-0,0000196$ and probability is 0,2202 means the international corn price has negative not significantly effect on ROA at level 95 percent confidence. That is, if there is an increase or decrease in international corn prices does not significantly influence ROA.

Thus insignifant influence was shown on price trend of international corn price decreased in 2012 through 2015 was not accompanied by an increase in ROA animal feed companies that turns declined. Insignifcant influence was due to exchange rate factors that have more influence on the price of imported corn and animal feed companies not using all imported corns for raw material needs but still have supplies from local corn. Insignifcant influence on international corn price also was due to corn demand as a main raw material for animal feed industry was provided and affect by local corn prices, livestock population and imported soy bean meal (SBM prices, the soy bean meal can be used as substitute products for corn as a raw material for animal feed (Ariyanti, 2008).

\section{Return on Assets (ROA)}

The animal feed company's profitability during study period had an average positive ROA value of 0,0238 means on average it's generate a positive return of 2,38 percent in net profit from every rupiah of total assets or every rupiah invested in asset value increases IDR 0.0238. It can be said for the period year 2010-2015 level of profitability of animal feed companies gain positive profitability value. The ROA movement of four animal feed companies 2010-2015 period had a downward trend (Figure 1) with highest ROA in the third quarter of 2010 by CPIN amounted to 12,19 percent and lowest ROA in the third quarter of 2015 by SIPD amounted to $-6,91$ percent. ROA trends began to improve in the fourth quarter of 2015 with positive values 1,19 percent.

Animal feed company with the highest ROA average is CPIN of 5.43 percent indicating CPIN efficiency advantage in achieving profitability. This efficiency advantage comes from a vertically integrated corporate structure where all assets owned in the downstream and medium businesses are supporting the upstream poultry feed business which is the main line, as seen from the asset productivity (TATO) in generating sales shows the best performance seen from The highest TATO values compared to competitors. Large business scale (economies of scale) CPINs have an 


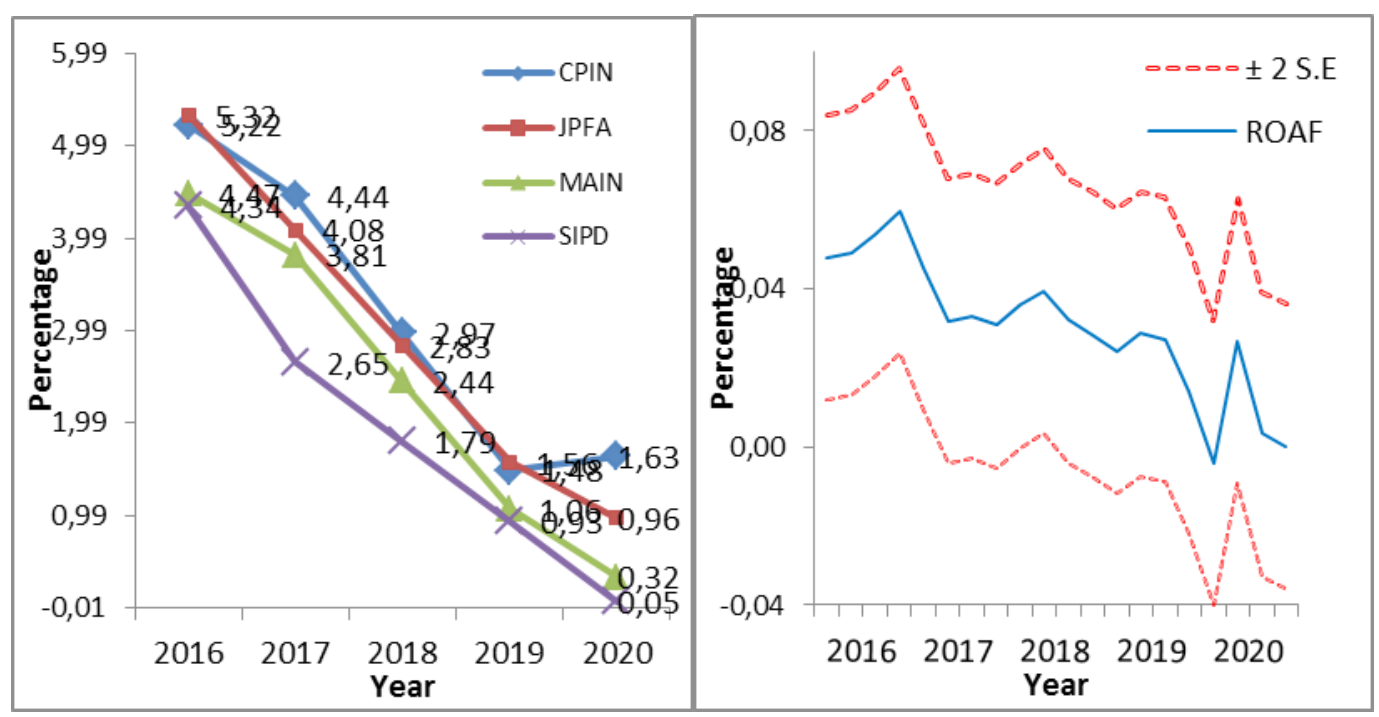

Figure 2 Company's ROA projection

advantage in purchasing large quantities of raw materials at low prices, as well as in production processes with high efficiency and low cost so as to depress COGS value and increase gross profit.

The average CPIN sales growth of 15 percent each year coupled with large economies of scale results in sales of large quantities of products, so even if the sales margin is small but large sales will increase profits. For corporate funding, CPIN is very cautious in using external financing of debt, reflected by low DAR values that minimize interest expense and bank administration and increase corporate profits. CPIN chooses internal funding from its operating profit and share sales investment, as it is known that good profitability and sales performance will make stock prices stable and increasing which attract investors to invest in CPIN shares.
The average ROA of MAIN of 2,68 percent is the second highest ROA among its competitors reflecting the superior efficiency of MAIN in achieving profitability. MAIN has an advantage in asset productivity level (TATO) generating sales of 1,12 times; this is derived from the vertical and intermediate business vertical integration structure and strategy of supporting the upstream animal business becoming the main business line. This asset productivity makes MAIN focus on selling poultry-based livestock products by generating an average sales growth of 19 percent each year which is the highest sales growth among competitors thus increasing profitability.

The level of profitability of JPFA is ranked third among competitors with an average ROA of 1,82 percent. Although known as the 2nd largest integrated livestock 
feed company, JPFA has a corporate structure focusing on several areas of protein: poultry, shrimp and cow and some subsidiaries unrelated to the main line making the JPFA structure inefficient and the company's strategy cannot focus only On one business line only, this makes the value of asset productivity to sales by 1,05 times and sales growth 13 percent per year lower than CPIN and MAIN. Companies with the lowest average ROA are SIPD with a value of $-0,41$ percent. Although the company structure has focused on one main line of feed and poultry products, but the productivity of the assets in generating sales is the lowest among its competitors which is $-0,42$ times. The low productivity of these assets makes the average sales growth of $-9,0$ per cent seen from the decline in sales since 2013 making SIPD less competitive in the animal feed industry. While more than 52 percent of total assets are funded using debt (DAR), the high operating expenses incurred by SIPD are not proportional to the sales revenue received earning the lowest level of profitability compared to competitors and experiencing operating loss.

Based on the result of regression panel data model output with R-squared value of 84,56 percent close to 100 percent value, then the model includes good (fit) in explaining the effect of independent variable to dependent variable and can be used for future projection. The projection is done by entering the assumption of the growth of independent variables on average into the regression model so as to get the value of Y projection. The projected graph of the company's ROA for 2010-2020 is presented in Figure 2.

Companies with the highest ROA projection are CPIN and JPFA. This high profitability is the result of the expansion and business scale of both companies which are able to meet the increasing demand of each consumer so as to get the highest profitability. The ROA value of MAIN is still stable above SIPD without negative earnings during the study period. The value of SIPD ROA shows improvement after it slumped in 2014 but still remains below all three competitors. It indicates that SIPD should prepare a better internal strategy in the future.

The projection of linear regression trend by regressed the dependent variable of ROA on time gives the average ROA value to four companies decreasing, similar to the ROA projection trend of each company as presented in Figure 2. The average ROA projection (ROAF) has decreased trend from 2016 to 2020, such as the average of ROA from 2010 to 2015, this is thought to be due to cyclical factors simultaneously faced by companies such as the exchange rate cycles and international corn prices will increase the company's production costs.

The average ROA increases in the first quarter to four years of 2016 such as 
ROA from 2010 to 2012, then declines until the first quarter of 2020. In the second quarter of 2020, the trend started to increase again but decreased in the third quarter of 2020. Increased ROA on yield the projection indicates a shorter ROA increase time of one year with a lower value than the increase in ROA from 2010 to 2012 and a decrease in projected ROA longer during 2017 to 2019 with a lower value than the 2012 ROA through 2015. Based on projections of the upper limit and down can be a description for the company to set the target value of ROA to reach eight percent but also must be wary of the impact of the challenges that will be facing make the decline of ROA to minus four percent.

Based on future projections, management knows the precise time prediction to determine the strategy and type of strategy to be undertaken thus minimizing the risk of decreasing profitability. As the ROA trend projection improves, it becomes the right moment for management to implement optimum profitability strategies such as setting high sales targets and developing corporate revenue sources. As the projected ROA trend declines, it is likely that the feed and livestock feed industry is experiencing a challenging period of industry and macroeconomics. due to the cyclical factors like exchange rates and international corn prices cycle, so management must do strategies to control risk of reduction in profitability as did spending efficiency and minimize the financial costs.

\section{Managerial Implications \\ Companies}

Implications for companies and animal feed industries to increase profitability were to give more priority in reduce the cost of goods sold where the increasing of the coefficient has more sensitive effect on ROA if paired with sales, TATO and kurs.

The strategy of suppressing the price of COGS to overcome the purchase of imported raw materials with high exchange rates as a large-scale agribusiness company with long-term vision in the animal feed industry competition must have facilities and R \& D network and product formulation innovation so as to enable using import substitute raw materials without reducing the quality. Also uses technological advancements that continue to evolve through automation, focusing on the implementation of international standardized production management, and cost savings at all operational levels with the goal of cost-efficiency production.

In addition, the company should monitor inventory levels which may vary according company scale, with referred to production plans and raw material requirements as well as an advance in the purchase of imported raw materials and purchase contracts quantity at a low 
price to obtain the best possible price. The company must also expand local raw material suppliers throughout Indonesia and also provide intensive assistance to local farmers in order to produce quality products to be utilized as a source of raw materials for production. In addition to efficiency of production process through cost savings at all operational levels and addition of raw material storage facilities.

In relation to the purchase of imported raw materials and the exchange rate, the company must closely monitor the fluctuations of foreign exchange rates and routinely hedge transactions on part of its foreign currency payables and conduct operational hedging for the payment of raw materials of forage stock Ahead of time by entering into a purchase contract at a low price, transferring the foreign currency denominated loan to the rupiah currency and providing cash in the form of US dollars. Adjustment of feed product prices should also be made to reduce the high COGS cost of the impact of the weakening exchange rate, only that adjustment adjusts the time to follow the amount of depreciation value.

The next implication is that the companies must increase sales one way by strengthening the marketing mix that has been running more focused on the product, place and promotion. Livestock feed business is highly influenced by supply and demand. Thus, to increase profitability can be done by increasing sales followed by increasing the volume (supply). The company can enlarge its its expansion by establishing a feed mill and establishing a new distribution network so as to penetrate strategic locations and open up new market potentials to Indonesia to bring products closer to consumers and facilitate consumer access to Distribution channels so that consumers do not need to look for alternative brands of other animal feed to build brand awareness.

The company must improve product quality by innovation of high quality animal feed formula in accordance with farmer's expectations with competitive price so as to give good brand image. To increase the purchase of livestock feed, companies can undertake a strategy of creating a market (creating demand), companies expanding DOC production, by acquiring or buying other company assets so that more DOCs in the market need cattle for cultivation. In addition to cooperate with each other mutually beneficial partnership between the company and contract farmers. This cooperation is aimed at maintaining market stability for DOC products and chicken feed produced by the company and maintaining continuity of raw material supply for the chicken and processed chicken industry.

Company can do promotion by building relationship marketing by interacting with marketing channel consisting of agent / distributor and poultry 
shop, empowering group / farmers society or directly to the consumer of farmer (direct farm) which become moment of facility Promotion of products and cooperation programs to attract interest and better relationships with consumers or targeting the main target of breeders both old breeders who have become consumers or ranchers of competitor products to seize market share.

After sales service strategy is also enhanced to build the company's brand image product with sales formula that is the ranks of marketing human resources and professional technical service support capable of handling any sales situation that may arise, able to communicate nimbly with the technique of digging the real needs of consumers so motivate from the desire to buy Become a necessity to buy. Then can overcome the complaints of the problems that occur also play a rancher in assisting management of cultivation of good livestock that creates more value beyond expectation in the minds of consumers as well as provide an opportunity to win the hearts of more customers who not only get the product, but also get a high quality service. With the brand awareness will form a brand image with the purpose of customer satisfaction resulting in repeat purchase or purchase intention to build customers loyalty.

The implication productivity of asset in generating sales (TATO) is that the company has large asset but not yet efficient so that it affects profitability. The company should implement efficiency strategy and focus on downstream and medium business which is the main supporting business line that is feed and poultry seed. While business lines that are not supporting the main line of business can be incorporated into a single management company or release its subsidiary shares. It is one of the efforts to shore up the future performance so that each business line can focus more on increasing TATO.

\section{Government}

The government is expected to ensure the availability of local feed raw materials such as maize that meet the Indonesian National Standard (SNI) at a reasonable price. The role of the government by making corn production centers throughout the vast archipelago, then providing assistance to corn farmers for the need for superior seeds, cultivation, drying and storage, and eliminating the monopoly in the supply of maize and cutting the distribution chain from farmers to factories Feed. The government is also asked to consider Government Regulation (PP) no. 77 of 2007 on import tariff of maize by five percent which is the burden of animal feed producers.

Government support is needed to achieve rupiah exchange rate stability, maintainable monetary stability and financial 
system stability, maintain high economic growth momentum and minimize inflation rate so that people's purchasing power increases. The government as a regulator is expected to pro-actively maintain a balance between supply and demand supply of seeds and chicken in the market so that the price becomes conducive and profitable for all parties. The government should also provide guidance and support to the farmers of the people in order to adopt the latest cultivation technology, as well as the regulation and supervision of the trading system on the length of the chain of chicken distribution which impacts the price from the farmers to the consumers. The role of government with animal feed companies in the supply of animal protein at affordable prices is expected to improve nutrition for the community.

\section{Investors}

Animal feed industry was able to gain positive profitability despite facing various industry and macroeconomic challenges. With a large population of Indonesia and the consumption rate of chicken meat purchased in the traditional market (wet market) about 80-90 percent is increasing from year to year making a bright future for the animal feed industry.

Investors who were interested investing in the animal feed industry can invest by buying the company's shares, where four major integrated livestock feed companies have been listed on the BEI, namely CPIN, JPFA, MAIN, SIPD and two companies are included in the LQ45 Index of CPIN and MAIN which are included in the stock Issuers with good financial condition, promising growth prospects, and high stocks and transaction frequency of stock transactions. Investors can also invest in the real sector in the vertical integration value chain of livestock feed companies, such as being a feedstock supplier that is a primary need for livestock feed companies to do production, work together in cattle farming partners, or invest in livestock processed food businesses. In addition Investors can also be a marketing channel of animal feed products that are agents / distributors and feed stores (poultry shop).

\section{CONCLUSION AND SUGGESTION Conclusions}

Internal factors that significantly affect ROA are sales, cost of goods sold (COGS), Total Asset Turnover (TATO) and external factors that significantly affect profitability is exchange rate. Variables Debt Asset Ratio (DAR), inflation rates, and international corn prices does not significantly effect ROA. Performance on average profitability (ROA) of large animal feed companies in Indonesia during the study period showed a positive result with the highest profitability are CPIN, MAIN, JPFA and lowest level of profitability is SIPD. 
The projection of ROA Company showed an increase in 2016 compared to 2015 , but this increase was not able to match the achievement of ROA in 2010, but in 2017 ROA decreasing trend until 2020. The company with the highest ROA projection is CPIN and JPFA, MAIN still stable above SIPDs without negative earnings and SIPDs showed an increase and improve after plunging in 2014, but still below the three competitors. The increase in ROA is thought to be caused by increased demand for animal protein in the community thus increasing the company's sales and support macroeconomic conditions for the animal feed industry.

\section{Suggestion}

This study used panel data balanced from animal feed companies in Indonesia period 2010 to 2015 which found that the profitability is influenced by diverse factors, both in terms of financial and nonfinancial. The study is expected further to investigate companies other animal feed as well as to include other financial factors that are supposed to influence as these costs, the enterprise market, economic growth, and the growth of incomes of the population. Non-financial variables may also be added such as current and latest strategy and business model of the animal feed company's, marketing and consumer behavior research on animal feed companies.

\section{REFERENCES}

Akotey, J.O., Sackey, F.G., Amoah, L., Manso, R.F. 2013. The financial performance of life insurance companies in Ghana. The Journal of Risk Finance. (14) : 286-302.

Almajali, A.Y., Alamro, S.A., Al-Soub, Y.Z. 2012. Factors affecting the financial performance of Jordanian insurance companies listed at Amman Stock Exchange. Journal of Management Research. (4) : 266-289.

Anum, F., \& Basri, M. 2014. Analisis pengaruh rasio aktivitas terhadap profitabilitas pada PT. Barata Indonesia (Persero) UUM Medan. Jurnal Riset Akuntansi dan Bisnis (14) : 176-187.

Ariyanti, D., Suryantini, A., Masyhuri. 2008. Permintaan Jagung Sebagai Bahan Baku Industri Pakan Ternak di Indonesia. Jurnal Agro Ekonomi (15) : 1-16.

Ashvin, R.D. 2012. Financial management as a determinant of profitability: a study of Indian pharmacy sector. South Asian Journal of Management (19) : 124-137.

Barus, A.C., \& Leliani. 2013. Analisis faktor-faktor yang mempengaruhi profitabilitas pada perusahaan manufaktur yang terdaftar di bursa 
efek Indonesia. Jurnal Wira Ekonomi Mikroskil (3) : 111-121.

Bhayani, S.J. 2010. Determinant of profitability in Indian cement industry: an economic analysis. South Asian Journal of Management. (17) : 6-20.

[DBS] Development Bank of Singapore. 2016. Indonesia industry focus animal protein. Research Report. Jakarta : PT DBS Vickers Securities ID page 10-11.

Dewi, L., \& Djawoto. 2015. Faktor-faktor yang mempengaruhi profitabilitas pada perusahaan air minum kemasan di BEI. Jurnal Ilmu dan Riset Manajemen (4) : 1-19.

Dwiarti, R. 2014. Evaluasi faktor-faktor yang mempengaruhi profitabilitas pada perusahaan manufaktur yang terdaftar di BEI. Jurnal SosioHumaniora (5) : 144-161.

Fitriani, A. 2006. Analisis Struktur, Perilaku dan Kinerja Industri Pakan Ternak Ayam di Propinsi Lampung dan Jawa Barat. Jurnal Agro Ekonomi (32) : 167-186.

[GPMT] Gabungan Perusahaan Makanan Ternak. 2016. Konsumsi Pakan Ternak Nasional 2015. Jakarta : Gabungan Perusahaan Makanan Ternak.
Gitman, L.J. 2009. Principles of Managerial Finance. $10^{\text {th }}$ Ed. Indiana : Addison Wesley.

Halim, C. 2013. Pengaruh variabel makroekonomi terhadap kinerja perusahaan di Indonesia pasca merger dan akuisisi. Jurnal FINESTA. (1) : 24-29.

Hidayat, W., Wahyuati, A. 2015. Analisis faktor-faktor yang mempengaruhi profitabilitas pada perusahaan semen yang terdaftar di BEI. Jurnal Ilmu Dan Riset Manajemen. (4) : 1-17.

Kalengkongan, G. 2013. Tingkat suku bunga dan inflasi pengaruhnya terhadap Return on Asset (ROA) pada industri perbankan yang go public di Bursa Efek Indonesia. Jurnal JEMBA. (1) : 737-747.

Karmilah, E. 2016. Analisis kinerja berbasis penciptaan nilai dan faktor-faktor yang mempengaruhi return saham industri pakan ternak. [Tesis] Bogor: Institut Pertanian Bogor.

Margaretha F, Supartika N. 2016. Factors affecting profitability of small medium enterprises (SMES) firm listed in Indonesia stock exchange. Journal of Economics, Business and Management (4) : 132-137. 
Nachrowi, N.D., \& Usman, H. 2006.

Pendekatan populer dan praktis ekonometrika untuk analisis ekonomi dan keuangan. Jakarta : Lembaga Penerbit Fakultas Ekonomi Universitas Indonesia.

Noor, A.S. 2011. Analisis faktor-faktor yang mempengaruhi kinerja keuangan perusahaan telekomunikasi yang go public di Bursa Efek Indonesia. Jurnal Ekonomi dan Akuntansi. (12) : 13-44.

[OECD] Organisation for Economic Cooperation and Development. 2015. Poultry meat projections: Consumption, per capita, in OECD-FAO Agricultural Outlook 2015, OECD Publishing. Paris (FR). http://www.oecd-ilibrary.org. [15 December 2016]

Okwo, I.M., Enekwe, C.I., \& Ugwunta, D.O. 2012. Financial management as a determinant of profitability: a study of selected pharmaceutical firms in Nigeria. European Journal of Business and Management (4) : 28-36.

Pervan, M. 2010. Determinants of insurance companies' profitability in Croatia. The Business Review Cambridge. (16) : 209-216.

Putu, N.N.G.M., Moeljadi, Djumahir, Djazuli, A. 2014. Faktor yang mempengaruhi nilai perusahaan manufaktur publik di Indonesia. International Journal of Business and Management Invention. (3) : 35-44.

Rice. 2014. Analisis faktor-faktor yang mempengaruhi profitabilitas perusahaan kompas 100 yang terdaftar di Bursa Efek Indonesia. Jurnal Wira Ekonomi Mikroskil (4) : 11-20.

Ruspandi, H., Asma, R. 2014. Faktor-faktor yang mempengaruhi profitabilitas perusahaan pembiayaan di Indonesia. Jurnal Wawasan Manajemen (2): 97-118.

Sanjay, J.B. 2010. Determinant of profitability in Indian cement industry: an economic analysis. South Asian Journal of Management (17) : 6-20.

Suardani, A.A.P. 2009. Pengaruh beberapa variabel ekonomi makro terhadap kinerja keuangan dan return saham perusahaan pada industri manufaktur di pasar modal Indonesia. Jurnal Sarathi (16) : 255-266.

Tangendjaja, B. 2007. Inovasi teknologi pakan menuju kemandirian usaha ternak unggas. Wartazoa. (17) : 12-20.

Wardjojo, C.A.I, Anggraeni, L., Sasongko, H. 2016. Pengaruh likuiditas 
modal kerja terhadap profitabilitas perusahaan sektor perunggasan yang terdaftar di bursa efek Indonesia. Jurnal Manajemen \& Agribisnis (13) : 206-216.
Winarno. 2015. Faktor-faktor yang memengaruhi profitabilitas perusahaan manufaktur yang listed di Bursa Efek Indonesia. Jurnal Economia. (11) : 143-149. 